\title{
Teaching Practice Outputs in Public and Private Secondary Schools in Nigeria: A Comparative Analysis
}

\author{
Ngozi Priscilla Okoro \\ Educational Foundation and Management, Federal College of Education \\ Nigeria
}

\begin{abstract}
This research evaluates the impact of teaching practice on teachers output in public and private secondary schools in Nigeria. The paper reviews literature on teacher education and comprehensively conceptualises the term teaching practice. The descriptive survey research design was adopted to investigate student-teachers who are going through the teaching practice (TP) scheme. The population of the study consists of third year pre-service teachers (Degree) University of Ibadan, Centre for Degree Programme, Federal College of Education, Abeokuta, Nigeria. A sample of one hundred and forty-four (144) third year pre-service teachers was selected for the study through stratified random sampling technique. In relation to student's performance, the average score for maths for public school $(68.76 \%)$ is higher than that for private school (59.12\%) and for English language the average score for private school (73.23\%) is higher than that of public school (51.25\%). For physics, the average score for private school (69.67\%) is slightly higher than that of public school (64.78\%) and for chemistry, the average score for private school (71.19\%) is slightly higher than that of public school $(58.25 \%)$. The study recommends for strategic efforts of all stakeholders in improving the quality of the teaching practice programme.
\end{abstract}

\section{Introduction}

The educational system has continued to experiment with numerous strategies and programs to bridge the gap between new teacher inexperience and the promotion of climates that foster positive educational outcomes. One of the programmes is the teacher training scheme or programme. The actual models in which it is done may vary for different climes, but most include an initial component during which student teachers observe class instruction by the mentor teacher. During this time, the intern may be asked to reflect upon the teaching, offer insights and suggest next steps in the instruction. After this period of observation, usually measured in a few weeks, the student-teacher begins to assume direct teaching responsibilities. Osuala [18] concluded that, teaching practice expose the trainee teacher to the realities of effective teaching and help them to try out methods of teaching and gain practical classroom experience under expect supervision. Wellington (2006) explained that, during the teaching practice, the trainee teachers are sent out from the University and College to primary, secondary, commercial, comprehensive and technical schools to teach for a period of time as a part of their training Teaching practice in the 21 st century is considered to be one of the most influential aspects of pre-service teacher education [21]. Feiman-Nemser and Buchman [5] suggest that the main task in teaching practice is to help the student teachers recognise the difference between going through the motions of teaching and connecting these activities to what pupils/students should be learning and this connection hopefully takes place during the student teacher's practicum experience. The length and duration of these practice experiences or practicums vary according to the university requirements. Teaching practice is an important component towards becoming a teacher. It provides experiences to student teachers in the actual teaching and learning environment. During teaching practice, a student-teacher is given the opportunity to try the art of teaching before actually getting into the real world of the teaching profession. Studentteachers also know the value of teaching practice and they perceive it as the important aspect of their preparation for the teaching profession since it provides for the real interface between student hood and membership of the profession [19]. The internship programme opens up the workplace and plays a primary and critical role in the student teacher's pedagogical growth and development through teaching practice under the supervision and guidance of an experienced teacher as a role-model [13].

The student-teacher intern is afforded the opportunity to develop skills and gain experience in the practical application of his/her theoretical course work. This combination of academic preparation and teaching-practice experience should ensure that professional classroom educators are thoroughly prepared to enter the workplace upon completion of their degree [11]. According to Nigerian National Universities Commission (NUC, 2007) Benchmark and National Commission for Colleges of Education (NCCE, 2015), the following sets of objectives have been established for why teaching practice is a mandatory component of teacher training. (i.) To expose student-teachers to real life, classroom experiences under the supervision of professional teachers, (ii) to provide the forum for student-teacher to translate educational theories and principles into practice, (iii). (iv) to enable student-teachers discover 
their own strengths and weaknesses in classroom teaching and provide opportunities to enable them address their weaknesses and enrich their strengths and (v) to provide student-teachers with an opportunity for further acquisition of professional skills, competencies personal characteristics and experience for full-time teaching.

It is well documented that teacher quality is the most important school-based factor associated with improving student achievement. Although teacher quality is critically important, the policy mechanisms through which it may be cultivated have proved elusive. For example, studies have shown that it is only weakly related to readily quantifiable teacher attributes like licensure status, degree, and experience levels [1]. Moreover, the empirical literature about policies designed to affect teacher quality such as pay for performance and professional development (e.g., [6]; [7]; [8]. The findings are mixed, however, relatively little quantitative research investigates the role of teaching practice [9], but there is a great deal of speculation that teacher practice [10] has a powerful influence on a teacher's later success. Consequently, the objective of the study is to examine the roles of teaching practice on educational outcomes.

\section{Literature Review}

\subsection{Concept of Teaching Practice}

According to Maduabum and Abah [12] in Uwameiye and Ogunbameru, teaching practice is a component of teacher education programme in which teacher trainees have the opportunity to put into practice all the teaching and classroom management theories they have acquired during the course of their studies with a view to attain professional competence. Olaitan and Ausiobo in Nakpodia [15] indicated that practice teaching is the phase of the pre-service education of teachers in which the student-teacher is given an opportunity to bring together educational theory and actual teaching procedures under competent supervision.

De-ville [4] stated that teaching practice is an internship experience, a part of formative training process for pre-service teachers in skills exploration and enhancement. Akbar [23] noted earlier that the term practice teaching embraces all the learning experiences of student teachers in schools. According to Teacher Training Regulation (2012) teaching practice is such a period of studies when the initial professional steps are made, when the attitude towards teachers' activity, right, obligations and responsibilities is shaped. It is the educational space where the quality of competencies acquired during the study is revealed. Teaching practice help preservice teachers acquire professional competencies and experience
Alkan and Demirhan in Basturk [2] indicated that, the general purpose of the teaching practice courses is to contribute to pre-service teachers ${ }^{\text {ee }}$ professional development by providing them, within the framework of the faculty and school cooperation, the opportunity to transform their content knowledge, pedagogical content knowledge and general cultural knowledge obtained from the faculty into practice. Teaching practice exposes pre-service teachers to new perspectives as well as prepares them in knowledge and skills. It equips them with knowledge of subject matter and pedagogical content knowledge or knowledge of how to teach Basturk [2]. Teaching practice offers the practicing students an opportunity to engage in profitable experiences in observing, sharing, participating and in teaching with the supervision of more experienced teachers [22].

\subsection{Prior Studies}

Msangya, Mkoma and Yihuan [14] examine the perspectives of undergraduate student teachers toward teaching practice experience as a tool of learning to teach. A qualitative research methods approach using semi - structure questionnaires was carried out to 351 second- and third-year undergraduate student teachers in the department of education of the Faculty of Science at Sokoine University of Agriculture. The findings indicate that the student teachers perceived teaching practice as an important tool of learning to teach because it promoted the development of teaching experience and prepared them for the real world of work. The results also revealed that teaching practice is sufficiently emphasised and lack of financial support and the mismatch of the teaching practice period with local secondary school calendar were the main challenges. The study recommends provision of adequate fund on time, close supervision, building strong university partnership with the local secondary schools need interventions if not be improved and given its due attention.

Harris and Sass [9] have generated models that include detailed measures of teacher training, developing a rich set of time-varying covariates that account for student and teacher characteristics. They find positive effects of content-focused teacher training on middle school and high school students, but not on elementary students. They also find that pedagogical training does not enhance teacher productivity

Bolarfinwa [3] study examine the effects of teaching practice on student teachers in tertiary institutions in Nigeria. A case study of 400 level students of the department of Arts and Social Science of Faculty of Education of the University of Lagos. Three hypotheses were formulated and 100 questionnaires were administered to student teachers from the department of Arts and Social Science, 
Faculty of Education. An analysis of the result obtained showed that teaching practice has never been a waste of time rather it has helped to inculcate the professional traits in student teachers, preparing them for the real classroom and school situation. This is the reason why in Nigerian universities, teaching practice is a compulsory course in the faculties of education which forms part of the prerequisites for graduation. However, observations have shown that there is a decline in the quality of teaching practice being offered in the universities now. It appears that teaching practice as being currently run in the universities is considered as inadequate.

There seems to be a lot of problems facing the prospective teachers in the course of carrying out the teaching practice exercise that seem to affect the effectiveness of the student teachers. Realistic experiences has shown that some of the problems inherent in teacher education can be traced to student teacher related problems such as mediocrity, low aptitude etc while some are institutions (universities) related problems such as weal curriculum, incompetent lecturers etc., and some are school of teaching practice related problems in form of poor supervision, mentoring and low motivation.

Andabai [24] evaluates the impact of teaching practice on trainee teachers in tertiary institutions in Nigeria: the Niger Delta University Experience. Questionnaire was used to collect the data; one hundred and twenty (120) students (respondents) from the faculty of education were selected using simple random sampling. The result showed that trainee teachers benefited greatly in participating in teaching practice because they were able to build proper confidence and competence in lesson preparation and developed skills and attitude of a teacher during the exercise. It was also revealed that teaching practice helps trainee teachers to learn how to keep records of assignment and also participating in school activities.

Uzoechina's study aim [20] was to ascertain the perception of lecturers on the impact of teaching practice exercise on student teachers' professional growth. Thus, the study investigated the perceived impact of teaching practice exercise on student teachers' professional growth in Anambra State of Nigeria. It was a descriptive survey design guided by three research questions. All the lectures in Faculty of Education, Nnamdi Azikiwe University, Awka formed the population of the study. From the lecturers, 60 of them were purposively selected for the study. The instrument used for data collection was a structured questionnaire with four-point option scale. The instrument was duly validated by experts and the reliability was also determined. The findings showed among other things that teaching practice helps student teachers to acquire knowledge which enhances the mastery of subject content areas. This to a very large extent leads to achievement of professional growth.

Oparah, Nwoke and Ikwuanusi [17] investigated the influence of teaching practice exercise on preservice teachers' professional development with regards to sustaining quality assurance of teacher education. The study adopted the descriptive survey research design. A sample of 420 pre-service teachers from Alvan Ikoku Federal College of Education Owerri Imo State, Nigeria were selected for the study through stratified random sampling technique. The instrument for data collection was researchers made 4-point likert type questionnaire titled "Teaching Practice Exercise and Teachers' Professional Development (TPETPD)". It had reliability coefficient of 0.79 determined using cronbach's alpha formula. The data generated was analyzed using mean and standard deviation to answer research questions while the hypotheses were tested using chi-square(x2) and t-test statistical tools at 0.05 level of significance. The result of the study revealed that teaching practice is very essential in pre-service teachers' professional development irrespective of gender. Kang and Berliner (2012), in their research, found that strong pre-service teacher training programs coupled with coherent induction systems led to far greater levels of teacher retention. However, in the same study, it was revealed that the retention of beginning teachers did not necessarily translate into success with regard to student outcomes.

\section{Methodology}

The descriptive survey research design was adopted to investigate student-teachers who are going through the teaching practice (TP) scheme. The population of the study consists of third year pre-service teachers (Degree) University of Ibadan, Centre for Degree Programme, Federal College of Education, Abeokuta, Nigeria. A sample of one hundred and forty-four (144) third year pre-service teachers was selected for the study through stratified random sampling technique. Particular attention was given to ensure the sample includes those doing their $\mathrm{TP}$ in private schools and those doing it in public schools. The instrument for data collection was a 4point likert type questionnaire titled Teaching Practice Exercise and Teachers. Professional Development (TPETPD) It ranged from Strongly Agree $(\mathrm{SA})=4$ pts, Agree $(\mathrm{A})=3 \mathrm{pts}$, Disagree $(\mathrm{D})$ $=2$ pts and Strongly Disagree $(\mathrm{SD})=1 \mathrm{pt}$. The face and content validity of the instrument were ascertained by two teacher educationists and a measurement and evaluation expert from the institution, their inputs guided the restructuring of the instrument. To determine reliability Cronbach's alpha formula was employed. The instrument was administered on face-to-face basis by the researchers. 
Student scores for maths, English language, Physic and Chemistry were obtained from selected private and public schools where these students-teachers were doing their TP. The data generated was analyzed using mean and standard deviation to answer research questions while the hypotheses were tested using chi-square (x2) and t-test statistical tools at 0.05 level of significance.

\section{Findings}

Moving to the analysis of the responses, the reliability testing using the Cronbach alpha statistics of 0.819 confirms the reliability of the research instrument. The analysis of the responses reveals that Majority of the respondents $(69.45 \%)$ provide a statistical validation that Teaching practice has made trainee teachers to master professional skills. $[\chi 2(1)$ $=5.78, \mathrm{p}<.05]$. The analysis of the responses shows that teaching practice has made trainee teachers learn how to plan, prepare and present their lesson topics. $[\chi 2(1)=6.20, p<.05]$ and this view held by a majority $(69.44 \%)$. The results from the analysis of responses reveals that Teaching practice helped trainee teacher to broaden their knowledge of the subject matter $[\chi 2(1)=7.01, p<.05]$ as this view is held by a majority $(68.75 \%)$. The results from the analysis of responses reveals that Teaching practice has help one to perfectly use instructional materials when teaching $[\chi 2(1)=6.80, p<.05]$ and this view is held by a majority $(72.18 \%)$. The perception that Teaching practice has made trainee teachers to observe the different features of school curriculum at work and how each contributes to learning is not statistically validated $[\chi 2(1)=0.18, \mathrm{p}>.05]$. The perception that Teaching practice has help trainee teachers to be familiar with school records and the complex set of rules and regulations is statistically validated $[\chi 2(1)=7.20, p<.05]$ as this perception is held by a majority $(68.05 \%)$. The view that teaching practice has helped one to gain valuable insight with regard to assessing his suitability for the teaching profession. $[\chi 2(1)=9.16, \mathrm{p}<.05]$ is statistically validated as this perception is held by a majority (\%) as this view is held by a majority $(66.67 \%)$. Going further, the survey analytics reveal that Trainee teachers see teaching practice as a vital factor in preparing student for future teaching assignment. $[\chi 2(1)=11.05, p<.05]$ and this view is held by a majority $(67.36 \%)$. Trainee teachers see teaching practice as a vital factor in preparing student for future teaching assignment $[\chi 2(1)=15.5, p<.05]$ as this view is held by a majority $(72.91 \%)$. The Teacher training programme enhances teacher productivity $[\chi 2(1)=6.33, \mathrm{p}<.05]$ as this view is held by a majority $(65.97 \%)$. On the overall, the findings reveals that corporate governance can be an effective tool for crime prevention and hence we reject the null hypothesis that corporate governance is not an effective tool for financial crime prevention and hence companies need to focus on ensuring a strong, independent and effective corporate governance system. On the overall, the results suggest that in-spite of all the challenges confronting teaching practice in the college, in particular and educational system in general in Nigeria, the exercise has impacted positively on the life of student teachers thereby leading to professional growth. The results of the study have a lot of implications for teaching practice in Nigeria educational institutions.

The analysis of the performance of students in Maths and English language for both private and public schools taught by teachers that have gone through the teaching practice scheme reveals that there is a significant difference in subject scores for both schools and the average score for maths for public school $(68.76 \%)$ is higher than that for private school $(59.12 \%)$ and for English language the average score for private school $(73.23 \%)$ is higher than that of public school (51.25\%). For Physics, the average score for private school $(69.67 \%)$ is slightly higher than that of public school $(64.78 \%)$ and for Chemistry, the average score for private school $(71.19 \%)$ is slightly higher than that of public school $(58.25 \%)$. On the overall, it appears that the effect of teaching practice on student's educational outcomes in private and public schools may be mixed and probably dependent also on several other contextual factors. Ofeimu and Kolawole [25] asserted that a critical look at the public secondary schools in Nigeria, reveals a preponderance of low quality of teachers in the schools. Ofeimu and Kolawole[25] observed that majority of the teachers were not computer-literate and were not even in the habit of accessing the internet for new ideas about the subject they teach but rather they continue to use and repeat the same learning materials for their students, year in, year out. Many public-school teachers are unable to develop themselves academically but continue to quote outdated principles of teaching and use archaic or obsolete methodologies for their poor and frustrated students [25].

It has been rumoured among a large number of people that teachers in public secondary schools are more academically qualified than teachers in the private schools. This assertion is based on the fact that teachers in public schools are supposed to have certification from a College of Education, or the Education Faculty of a University thus making them professionally qualified to teach haven gone through teaching practice. Teachers in private secondary schools however usually just have academic qualifications with little professional qualification [25]. 
Table 1. Survey Analysis of Teaching Practice effects on Student Teachers in Private and Public Secondary Schools

\begin{tabular}{|c|c|c|c|c|c|c|c|c|}
\hline \multicolumn{5}{|c|}{ Demographic Variables } & \multicolumn{3}{|c|}{$\mathrm{Nu}$} & $\%$ \\
\hline \multirow[t]{4}{*}{ Q1: Age } & \multicolumn{4}{|c|}{ 1) $15-20$} & \multicolumn{3}{|c|}{10} & $\{6.94\}$ \\
\hline & \multicolumn{4}{|c|}{ 2) $21-25$} & \multicolumn{3}{|c|}{53} & $\{36.81\}$ \\
\hline & \multicolumn{4}{|c|}{ 3) $26-30$} & \multicolumn{3}{|c|}{67} & $\{46.53\}$ \\
\hline & \multicolumn{4}{|c|}{ 4) 30-Above } & \multicolumn{3}{|c|}{14} & $\{9.72\}$ \\
\hline Q2: Gender & \multirow{2}{*}{\multicolumn{3}{|c|}{$\begin{array}{l}\text { 1) Male } \\
\text { 2) Female }\end{array}$}} & & \multirow{2}{*}{\multicolumn{3}{|c|}{$\begin{array}{l}\{84\} \\
\{60\}\end{array}$}} & $\{58.33\}$ \\
\hline & & & & & & & & $\{41.67\}$ \\
\hline \multirow[t]{4}{*}{ Q4: Marital Status } & \multicolumn{4}{|c|}{ 1) Single } & \multicolumn{3}{|c|}{130} & $\{90.28\}$ \\
\hline & \multicolumn{4}{|c|}{ 2) Married } & \multicolumn{3}{|c|}{14} & $\{9.72\}$ \\
\hline & \multicolumn{4}{|c|}{ 3) Divorcee } & \multicolumn{3}{|c|}{0} & $\{0\}$ \\
\hline & \multicolumn{4}{|c|}{ 4) Widow/widower } & \multicolumn{3}{|c|}{0} & $\{0\}$ \\
\hline \multicolumn{9}{|c|}{ Teaching Practice effects on Student Teachers } \\
\hline & \multicolumn{8}{|c|}{ Cronbach Alpha $=0.819$} \\
\hline & SA & $\mathrm{AG}$ & UN & $\mathrm{DA}$ & SD & $\mathrm{df}$ & $\chi^{2}$ & prob \\
\hline \multirow{2}{*}{$\begin{array}{l}\text { Teaching practice has made trainee } \\
\text { teachers to master professional skills. }\end{array}$} & 60 & 40 & 5 & 17 & 22 & 4 & 5.78 & $\mathrm{P}<0.05$ \\
\hline & $41.67 \%$ & $27.78 \%$ & $3.47 \%$ & $11.80 \%$ & $15.28 \%$ & & & \\
\hline \multirow{2}{*}{$\begin{array}{l}\text { Teaching practice has made trainee } \\
\text { teachers learn how to plan, prepare and } \\
\text { present their lesson topics. }\end{array}$} & 55 & 45 & 5 & 14 & 25 & 4 & 6.20 & $\mathrm{P}<0.05$ \\
\hline & $38.19 \%$ & $31.25 \%$ & $3.47 \%$ & $9.72 \%$ & $17.36 \%$ & & & \\
\hline \multirow{2}{*}{$\begin{array}{l}\text { Teaching practice helped trainee teacher to } \\
\text { broaden their knowledge of the subject } \\
\text { matter. }\end{array}$} & 34 & 65 & 9 & 20 & 16 & & 7.01 & $\mathrm{P}<0.05$ \\
\hline & $23.61 \%$ & $45.14 \%$ & $6.25 \%$ & $13.89 \%$ & $11.11 \%$ & 4 & & \\
\hline \multirow{2}{*}{$\begin{array}{l}\text { Teaching practice has help one to perfectly } \\
\text { use instructional materials when teaching. }\end{array}$} & 67 & 37 & 10 & 15 & 15 & 4 & 5.83 & $\mathrm{P}<0.05$ \\
\hline & $46.52 \%$ & $25.69 \%$ & $6.94 \%$ & $10.42 \%$ & $10.42 \%$ & & & \\
\hline \multirow{2}{*}{$\begin{array}{l}\text { Teaching practice has made trainee } \\
\text { teachers to observe the different features of } \\
\text { school curriculum at work and how each } \\
\text { contributes to learning. }\end{array}$} & 33 & 20 & 19 & 40 & 32 & 4 & 0.18 & $P>0.05$ \\
\hline & $22.91 \%$ & $13.89 \%$ & $13.19 \%$ & $27.78 \%$ & $22.22 \%$ & & & \\
\hline \multirow{2}{*}{$\begin{array}{l}\text { Teaching practice has help trainee teachers } \\
\text { to be familiar with school records and the } \\
\text { complex set of } \\
\text { rules and regulations }\end{array}$} & 60 & 38 & 6 & 22 & 18 & & 7.20 & $\mathrm{P}<0.05$ \\
\hline & $41.67 \%$ & $26.38 \%$ & $4.16 \%$ & $15.28 \%$ & $12.5 \%$ & 4 & & \\
\hline \multirow{2}{*}{$\begin{array}{l}\text { Teaching practice has helped one to gain } \\
\text { valuable insight with regard to assessing } \\
\text { his suitability for the teaching profession. }\end{array}$} & 34 & 62 & 10 & 18 & 20 & 4 & 9.16 & $\mathrm{P}<0.05$ \\
\hline & $23.61 \%$ & $43.06 \%$ & $6.94 \%$ & $12.5 \%$ & $13.89 \%$ & & & \\
\hline
\end{tabular}




\begin{tabular}{|l|c|c|c|c|c|c|c|c|}
\hline Trainee teachers see teaching practice as a & 55 & 42 & 7 & 25 & 15 & 4 & 11.05 & $\mathrm{P}<0.05$ \\
\cline { 2 - 11 } $\begin{array}{l}\text { vital factor in preparing student for future } \\
\text { teaching assignment. }\end{array}$ & $38.19 \%$ & $29.17 \%$ & $4.86 \%$ & $17.36 \%$ & $10.42 \%$ & & & \\
\hline $\begin{array}{l}\text { Teacher training programme improves } \\
\text { teacher and teaching quality }\end{array}$ & 57 & 48 & 5 & 20 & 14 & 4 & 15.5 & $\mathrm{P}<0.05$ \\
\cline { 2 - 13 } & $39.58 \%$ & $33.33 \%$ & $3.47 \%$ & $13.89 \%$ & $9.72 \%$ & & & \\
\hline $\begin{array}{l}\text { Teacher training programme enhances } \\
\text { teacher productivity }\end{array}$ & 48 & 47 & 4 & 20 & 25 & 4 & 6.33 & $\mathrm{P}<0.05$ \\
\cline { 2 - 11 } & $33.33 \%$ & $32.64 \%$ & $2.78 \%$ & $13.89 \%$ & $17.36 \%$ & & \\
\hline
\end{tabular}

Table 2. Survey Analysis of Subject Scores in Private and Public Secondary Schools

\begin{tabular}{|l|l|c|c|c|c|}
\hline & Private school & Public School & Df & t-stat & prob \\
\hline Maths Average scores & & & & & \\
\hline & $59.12 \%$ & $68.76 \%$ & 4 & 15.78 & $\mathrm{P}<0.05$ \\
\hline English language Average scores & & & & & \\
\hline & $73.23 \%$ & $51.25 \%$ & 4 & 16.20 & $\mathrm{P}<0.05$ \\
\hline Physics Average scores & & & & & \\
\hline & $69.67 \%$ & $64.78 \%$ & 4 & 2.78 & $\mathrm{P}>0.05$ \\
\hline Biology Average scores & & & & & \\
\hline & $71.19 \%$ & $58.25 \%$ & 4 & 14.20 & $\mathrm{P}<0.05$ \\
\hline
\end{tabular}

Despite this however, parents continue to take their children or wards to the private schools for those who can afford the tuition, with the reason being that the quality of teaching in the private schools is far better than those in public schools and also that the academic performance of students in private schools is better than that of their counterparts in public secondary schools [25]. Despite the argument that teachers in public secondary schools are perceived to be more professionally qualified than teachers in private schools, their professionalism is not reflected in the academic performance of their students, which is very disappointing.

Ofeimu and Kolawole [25] argued that teachers in private secondary schools irrespective of their qualifications tend to be more dedicated to duties in terms of lesson delivery and commitment to goal actualization as compared to their counterpart in public secondary schools who despite their teaching practice experience and professionalism fall far short of quality teaching standards. Parents therefore have preference for private secondary schools for their children because of some factors such as teacher commitment and dedication to duty, availability of staff, facilities, class size, curriculum practices, stability of academic calendar, disciplinary concerns and overall output as compared to public secondary schools with their myriad of inane problems [25].

\section{Conclusion}

There are multiplicities of challenges facing teachers in public secondary schools and the origin of these problems can be traced in many cases to their nasty and discouraging experience during the teaching practice exercise. The teaching practice exercise was designed to teach teachers to be teachers but the inadequacy of personnel and logistics to implement it has made the exercise ineffective with regards to achieving the goals for which it was set up.

The fact that many student-teachers are inadequately prepared for the exercise deprives them from attaining the necessary experience, skills and confidence they need when they eventually take up the teaching job. This faulty gap in teaching experience reveals itself when such potential teachers take up the teaching job usually in a public school.

Since teaching practice exposes student-teachers to the actual teaching and learning environment in which they can contextualise the theoretical knowledge gained during training, it also affords 
student teachers an opportunity to determine whether they have made the appropriate career choice or not. This should have been a turning point for many potential teachers to opt out of teaching as agreed on by student-teacher and supervisors but too many candidates not cut out to be teachers are allowed to cross this hurdle thus becoming a future burden to the school system.

\section{Recommendations}

In order to make teaching practice more meaningful as an instrument of professionalism among student-teachers who intend to teach in public or private schools, the following recommendations were made:

- Student-teachers should be exposed to proper orientation before going on teaching practice exercise. Potential teachers should be exposed to micro-teaching before being sent to face students. The experience of practicing with their own colleagues will give them a taste of what teaching feels like and motivate them to do it better when they will be tested on the field.

- Teaching practice exercise should not be a short term endeavour but should span about six months to ground the aptitude, attitude and competence of prospective teachers. More time should be devoted to this very important aspect of teaching.

- Since teaching practice is a curricular exercise, it behoves on the institutions to have agreement with the schools where student-teachers will carry out their practical teaching. This will rule out the incessant cases of rejection of candidates and boost morale. Thus, before and during each teaching practice session there should be thorough public relations groundwork undertaken by the institution in order to maintain good relations between the student teachers and all relevant role players.

- No matter how impactful teaching practice is for student-teachers, their competence will be jeopardised if they are not well remunerated as teachers. This is the bane of the teaching profession in public school. In this light the government should provide teachers with good pay and proper motivation so that they can compete meaningfully with their private secondary school counterparts.

- The teaching practice exercise must be used as a selection instrument for good teachers. It takes a certain type of person to be a teacher as such the exercise should be used to qualify those who can be good teachers and to disqualify those who are not teacher material. By so doing only those who can teach very well will graduate as teachers. This will do public schools and by default private schools a lot of good.

\section{Conclusion}

On the overall, it appears that the effect of teaching practice on student's educational outcomes in private and public schools may be mixed and probably dependent also on several other contextual factors. The study recommends for strategic efforts of all stakeholders in improving the quality of the teaching practice programme.

\section{References}

[1] Aaronson, D., Barrow, L., and Sander, W. (2007). Teachers and student achievement in the Chicago public high schools. Journal of Labor Economics 25: 95-135.

[2] Basturk, S. (2016). Examining primary preservice teachers' perspectives on teaching practice courses. Acta Didactien Napocensia, 9(3), 35 - 45.

[3] Bolarfinwa, O (2010). Effects of teaching practice on student teachers in tertiary institutions in Nigeria. Retrieved from https://www.grin.com.

[4] De-Ville, P. (2010). Mentioning reflective practice in pre-service teachers.

[5] Feiman-Nemser, S., and Buchman, M. 1987. When is student teaching teacher education? Teaching and Teacher Education, 3 pp. 255-273.

[6] Fryer Jr, R. G., Levitt, S. D., List, J., \& Sadoff, S. (2012). Enhancing the efficacy of teacher incentives through loss aversion: a field experiment (No. w18237). National Bureau of Economic Research.

[7] Glazerman, S., \& Seifullah, A. (2010). An evaluation of the Teacher Advancement Program (TAP) in Chicago: Year two impact report. Mathematica Policy Research, Inc.

[8] Goldhaber, D. and Anthony, E. (2003). Teacher Quality and Student Achievement. New York: ERIC Clearinghouse on Urban Education.

[9] Harris, D. N., and T. Sass. 2011. "Teacher Training, Teacher Quality, and Student Achievement." Journal of Public Economics 95 (78): 798-812.

[10] Levine, A. (2006). Educating schoolteachers. Report for The Education Schools Project, September 2006.

[11] Linn, P.L., Howard, A. and Miller, E. (Eds.) (2004). Handbook for Research in Cooperative Education and Internships. Mahwah, NJ: Lawrence Erlbaum Publishers. 
[12] Maduabum L, Abah O (2004). Lecturers' Assessment of Teaching practice Exercise in Nigerian Universities. J. Educ. Res. 6:65:74.

[13] Mecca, J. (2010). Case study of supervising a student teacher: Its impact on the cooperating teacher's professional development. Submitted in partial fulfilment of the requirements for the degree of Doctor of Education in Teacher's College, Columbia University.

[14] Msangya, B, Mkoma, S \& Yihuan, W., (2016). Teaching Practice Experience for Undergraduate Student Teachers: A Case Study of the Department of Education at Sokoine University of Agriculture, Tanzania. Journal of Education and Practice,7(14) 12-35.

[15] Nakpodia, E. D. (2011). Teacher and the student practice teaching programme in Nigerian educational system. International Journal of Educational Administration and Policy Studies, 2(3), 33 - 39.

[16] National Universities Commission, (2007). Benchmark minimum academic standards for undergraduates programmes in Nigerian Universities. Retrieved from fuwukari.edu.ng.

[17] Oparah, J., Nwoke, B, \& Ikwuanusi, N. (2017). Influence of Teaching Practice Exercise on Preservice Teachers' Professional Development Journal of Research \& Method in Education 7(5) 34-39.

[18] Osuala, E. C. (2004). Foundations of Vocational Education 5th ed. Enugu: Cheston Agency Ltd.

[19] Rakesh Ranjan, (2013). A Study of Practice Teaching Programme: A Transitional Phase for Student Teachers. Voice of Research 1(4), 1-5.

[20] Uzoechina, G (2015). Lecturers' Perception on Impact of Teaching Practice Exercise on Student Teachers' Professional Growth Anambra State. Journal of Emerging Trends in Educational Research and Policy Studies 6(3): 257-261.

[21] Haigh, M. (2001). Coherence and Congruence of Perceived Roleswithin Practicum Partnerships. A CaseStudy Paper Presented at the New Zealand Association for Research in Education Annual Conference, Christchurch, New Zealand. December 6-9, 2001.

[22] Cohen, L., Manion, L., \& Morrison K. (2011). Research methods in Education, (7th edition)

U.S.A: Routledge.

[23] Akbar, R. A. (2002). A study of practice teaching of prospective teaching model. Unpublished
Ph.D Thesis, Arid Agricultural University, Rawalpindi.

[24] Andabai, P. 2013 Sep 19. The Impact of Teaching Practice on Trainee Teachers in the Nigerian Tertiary Institutions: The Niger Delta University Experience. Academic Journal of Interdisciplinary Studies. [Online] 2:5.

[25] Ofeimu, J., Kolawole, B.O., (2017). Teacher Quality as Determinant of Students' Academic Performance in Secondary Schools in Edo South Senatorial District of Nigeria. British Journal of Education.Vol.5, No.13, pp.19-30, December 2017. ISSN 2055-0111(Print), ISSN 2055-012X (Online). 